\title{
Spatial and temporal anoxia in single-osculum Halichondria panicea demosponge explants studied with planar optodes
}

\author{
Lars Kumala $^{1,2}$ (1) $\cdot$ Morten Larsen ${ }^{1} \cdot$ Ronnie N. Glud ${ }^{1,3,4,5} \cdot$ Donald E. Canfield ${ }^{1,3}$
}

Received: 3 May 2021 / Accepted: 11 October 2021 / Published online: 3 November 2021

(c) The Author(s) 2021

\begin{abstract}
The water flow through sponges is regulated by their contractile behaviour including contraction and expansion of the aquiferous system, which leads to shifting oxygen levels in the sponge interior. Still, knowledge of spatial and temporal anoxia in sponges is lacking, but important in elucidating interactions between sponge hosts and their microbiomes. We combined 2-D luminescence lifetime imaging of oxygen with simultaneous time-lapse recordings of the sponge exhalant opening (osculum) to unveil temporal as well as spatial oxygen dynamics caused by contractile behaviour in single-osculum explants of the demosponge Halichondria panicea. The present study reveals an intrinsic concentric deoxygenation pattern in explants during episodes of osculum contraction generating an oxygen gradient with increasing concentrations towards the explant periphery. Four sponge explants faced 25 episodes with substantial changes in internal oxygen and anoxia which prevailed for $4.4 \mathrm{~h}$ of the total $92.0 \mathrm{~h}$ observation period. The 2-D images revealed that the total area of the explant experiencing anoxia during periods of osculum contraction-expansion varied between 0.01 and $13.22 \%$ and was on average $7.4 \pm 4.4 \%$ for all sponge explants. Furthermore, oxygen respiration, as approximated by the rate of change of oxygen concentration during deoxygenation of the explant interior, was similar throughout the oxic parts of the explant base. The resolved 2-D dynamics provide an unprecedented insight into the internal $\mathrm{O}_{2}$ distribution of sponges and complement the traditional point measurements of oxygen sensors.
\end{abstract}

Keywords Oxygen $\cdot$ Planar optode $\cdot$ Contractile behaviour $\cdot$ Diffusive oxygen uptake $\cdot$ Sponge explant $\cdot$ Anoxia

Responsible Editor: D. Gochfeld.

Lars Kumala

kumala@biology.sdu.dk

1 Nordcee, Department of Biology, University of Southern Denmark, 5230 Odense M, Denmark

2 Marine Biological Research Centre, University of Southern Denmark, 5300 Kerteminde, Denmark

3 Danish Institute for Advanced Study (DIAS), University of Southern Denmark, 5230 Odense M, Denmark

4 Danish Center for Hadal Research, University of Southern Denmark, 5230 Odense M, Denmark

5 Tokyo University of Marine Science and Technology, 4-5-7 Konan, Minato-ku, Tokyo 108-8477, Japan

\section{Introduction}

Sponges are sedentary filter-feeding invertebrates that are characterized by a 'simple' body plan designed to obtain suspended food particles and oxygen by active waterpumping. In sponges, water pumping is accomplished by the beating flagella of choanocytes, which are arranged in choanocyte chambers to maintain unidirectional water flow through a complex internal aquiferous system composed of inhalant and exhalant canals (Fig. 1a; Kilian 1952; Fjerdingstad 1961; Larsen and Riisgård 1994; Leys et al. 2011). Food particles, including bacterial and phytoplankton cells, enter the canal system through numerous pores (i.e. ostia) along the outer sponge surface (exopinacoderm). Large phytoplankton cells and other particles of $>5 \mu \mathrm{m}$ are phagocytosed in the inhalant water canal system, while freeliving bacteria and other picoplankton cells are retained by the choanocyte collar filter (Fjerdingstad 1961; Brill 1973; Leys et al. 2011). The water flow through this complex canal system oxygenates the sponge interior, in addition to the 


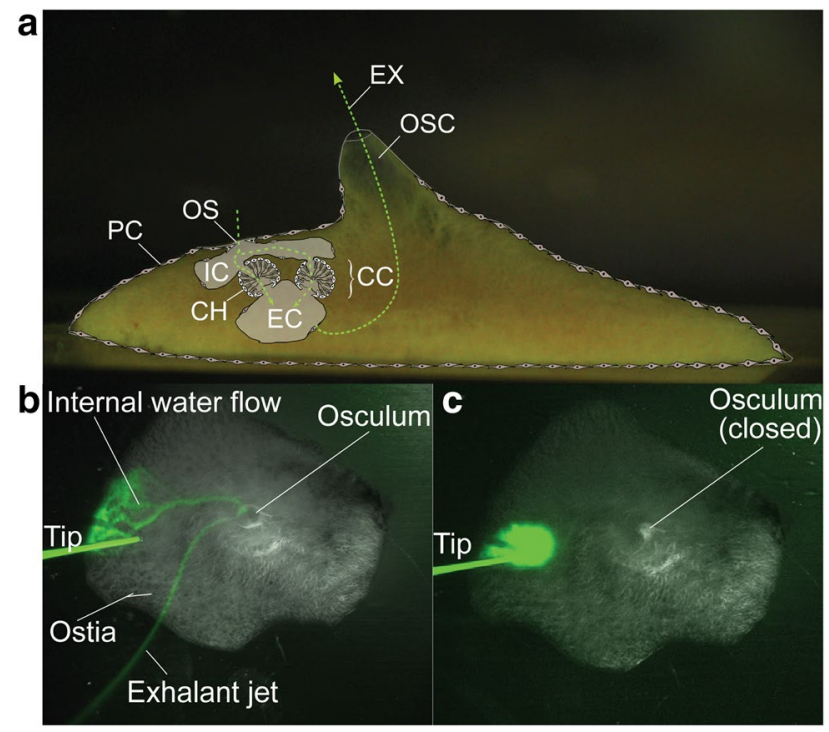

Fig. 1 a Side-view of a single-osculum sponge explant including a schematic illustration of the sponge anatomy. $P C$ pinacoderm, $O S$ ostia, $I C$ incurrent canal, $\mathrm{CH}$ choanocyte, $\mathrm{CC}$ choanocyte chamber, $E C$ excurrent canal, $E X$ exhalant jet, $O S C$ osculum. Green dashed line indicates the water flow through the sponge. Top-view of $\mathbf{b}$ expanded, i.e. actively pumping and contracted $H$. panicea sponge explant. Uptake, internal flow and release of water is visualized by green fluorescent dye filled into a small glass tip (see also Kumala et al. 2017; Goldstein et al. 2019)

diffusive flux of oxygen across the exopinacoderm (Kumala and Canfield 2018).

Sponges possess contractile behaviour, although they lack true organs, muscles (Pavans de Cecatty 1986, 1989) and a nervous system (Jones 1962; Pavans de Cecatty 1974). Such contractile behaviour is coordinated by actin microfilaments, myocytes and actinocytes abundantly located in the pinacoderm, canal system and the exhalant opening known as the osculum (Prosser et al. 1962; Elliott and Leys 2007; Nickel et al. 2011). Contraction and expansion of the sponge body, as well as the inhalant openings (ostia) and the oscula (Prosser et al. 1962; Reiswig 1971; Gaino et al. 1991; Nickel et al. 2006; Elliott and Leys 2007; Strehlow et al. 2016), arrest the sponge's pumping activity in regular or irregular intervals, which may further result in periodic, internal anoxia (Hoffmann et al. 2005a, 2008; Kumala and Canfield 2018; Mills and Francis et al. 2018). The diminished oxygen supply during pumping cessation may change the redox state of the sponge interior (Kumala and Canfield 2018), which is colonized by highly diverse microbial consortia (e.g. Taylor et al. 2007; Thomas et al. 2016; Moitinho-Silva et al. 2017; Lurgi et al. 2019).

The activity and abundance of these sponge-associated microbial consortia have previously been highlighted as functionally important for sponge metabolism and ecologically vital for marine ecosystems (Southwell et al. 2008;
Engelberts et al. 2020). For instance, both the aerobic (e.g. nitrification) and anaerobic (e.g. denitrification) processes of associated microorganisms may allow for recycling of waste products within the sponge body (Hoffmann et al. 2009; Zhang et al. 2019). Alternatively, the efflux of dissolved inorganic nutrients, such as nitrate (Corredor et al. 1988; Keesing et al. 2013; Hoer et al. 2018), by both high microbial abundance (HMA) and low microbial abundance (LMA) sponges, may considerably contribute to nutrient fluxes into otherwise oligotrophic environments, such as Florida Bay (Southwell et al. 2008; Hoer et al. 2020). Because of the ability of sponges to process a volume of water of up to 35 times their own body volume per minute (Weisz et al. 2008), sponge communities are increasingly recognized as 'key engineers' for nutrient and resource cycling in reef ecosystems (De Goeij et al. 2017). Although shifting internal redox states due to sponge behaviour may greatly affect the activity of the sponge microbiome, and ultimately nutrient fluxes in marine ecosystems, knowledge of spatial as well as temporal oxygen dynamics in sponges is scarce. This scarcity of information is probably due to the limitations of conventional techniques used to record oxygen in sponges, such as oxygen microsensors (Schönberg et al. 2004).

Transparent oxygen-sensitive planar optodes, combined with luminescence lifetime imaging systems, are promising alternatives for exploring spatial, as well as temporal, oxygen dynamics in biological samples (Glud et al. 1996; Holst et al. 1998), including corals (Kühl et al. 2008), sediments (Glud et al. 2005; Kühl et al. 2007) and biofilms (Glud et al. 1998; Staal et al. 2011; Prest et al. 2012). They have also been used in complex benthic environments such as animal burrows (Volkenborn et al. 2010) and in marine plant root systems (Frederiksen and Glud 2006). We applied here, for the first time, modular luminescence lifetime imaging (Holst et al. 1998; Holst and Grunwald 2001) to determine 2-D temporal and spatial changes in internal oxygen concentration in single-osculum explants of the demosponge Halichondria panicea. We combined oxygen imaging with time-lapse video observations of sponge behaviour to further elucidate the relationship between internal oxygen dynamics and contraction-expansion behaviour in these sponges.

\section{Methods}

\section{Optode preparation}

The measuring principle of planar optodes is based on the dynamic quenching of luminescence of an immobilized indicator by $\mathrm{O}_{2}$ (DeGraff and Demas 2005). We used the $\mathrm{O}_{2}$ quenchable luminophore PtTFPP (Platinum(II)-5, 10,15,20tetrakis-(2,3,4,5,6-pentafluorphenyl)-porphyrin (frontiersci. com), which possess an excellent photostability and long 
luminescent lifetime (Borisov and Klimant 2007). The brightness of the indicator was enhanced using Coumarin C545 (SigmaAldrich.com) as an antenna dye (Larsen et al. 2011). We prepared a sensor cocktail using PtTFPP and Coumarin C545 mixed in a 1/2\% (wt/wt) ratio, along with $4 \%$ (wt/wt) polystyrene dissolved in toluene (Larsen et al. 2015). The sensing cocktail was spin-coated onto $75 \times 50 \times 3 \mathrm{~mm}$ fiber optic faceplates (Schott Std. 47A Glass) to reduce the effect of optical smearing (Fischer and Wenzhoefer 2010). The final thickness of the highly transparent $\mathrm{O}_{2}$ sensor layer was $\sim 2-5 \mu \mathrm{m}$ and the sensing dye had an estimated reponse time of $<5 \mathrm{~s}$. These planar optodes were glued with transparent silicone into the front side of a custom-built plexiglas flume $(24.5 \times 8.5 \times 5 \mathrm{~cm})$.

\section{Preparation and cultivation of sponge explants}

Single-osculum explants of the demosponge Halichondria panicea were obtained from cuttings of specimens harvested from Kertinge Nor on the island of Fyn in Denmark. The sponge cuttings $\left(\sim 100 \mathrm{~mm}^{3}\right)$ were placed on the planar optodes after submerging the flume in an aquarium $(30 \mathrm{~L})$ with a constant flow of well-aerated bio-filtered (Mytilus edulis) seawater $\left(\sim 15^{\circ} \mathrm{C}\right.$, salinity of $\left.\sim 18-22\right)$. These cuttings attached onto the planar optodes within 3-6 days and developed an osculum in the subsequent 5-10 days, initiating regeneration of the water canal system and thus, active filter-feeding. These single-osculum explants were regularly (i.e. 1-2 times day $^{-1}$ ) fed with lab-cultured Rhodomonas salina algal cells $\left(\sim 5000\right.$ cells $\left.\mathrm{mL}^{-1}\right)$ prior to and during the experiment. Experiments were performed on explants $(n=4)$ that showed pumping activity, as verified by the uptake and release of a fluorescent dye (Fig. 1b, c). Further details on the preparation and cultivation of sponge cuttings are found in Kumala et al. (2017).

\section{Lifetime imaging system and image calibration}

We applied modular luminescence lifetime imaging (Holst et al. 1998; Holst and Grunwald 2001) to determine oxygen concentrations as measured by the planar optodes at the base of the single-osculum explants (Fig. S1). The luminescent lifetime $(\tau)$ of the $\mathrm{O}_{2}$ quenchable luminophore was inferred from bottom-view luminescence intensity images acquired within two well-defined time frames on the luminescent decay curve (i.e., after light excitation of the sensor; cf. Staal et al. 2011). Images were recorded with a fast gateable, Peltier-cooled charge-coupled device (CCD) 12-bit camera (SensiCam, PCO.de) equipped with a $560 \mathrm{~nm}$ longpass filter (UQGoptics.com). Excitation light was delivered by five blue high-power LEDs (LXHL-LR3C, Luxeon.com). Image acquisition and light-pulse excitation were synchronized through a custom-made triggerbox controlled by the software Look@Molli (Holst and Grunwald 2001). Images were recorded using a 16-image average and $1 \times 1$ binning to increase the signal-to-noise ratio. Images were further processed in ImageJ (Version1.47 g).

Recorded images were calibrated using the modified Stern-Volmer equation (Eq. 1; Klimant et al. 1995).

$\tau / \tau_{0}=\left[\left(\alpha+(1-\alpha)\left(1 / 1+K_{s v} \times C\right)\right]\right.$

where $\tau_{0}$ and $\tau$ are the luminescent lifetimes at anoxia and in the presence of any given $\mathrm{O}_{2}$ concentration $C$, respectively. $K_{s v}$ is the quenching coefficient and $\alpha$ represents the nonquenchable fraction of the signal. Both $K_{s v}$ and $\alpha$ were estimated by non-linear curve fitting the inverse of the Stern-Volmer $\left(\tau_{0} / \tau\right)$ plotted as a function of $\mathrm{O}_{2}$ levels (Staal et al. 2011), using the average lifetime from three randomly selected areas (each containing $\sim 625$ pixels) in images recorded at known oxygen levels $(\sim 98 \%, \sim 70 \%, \sim 5$ $4 \%, \sim 34 \%, \sim 16 \%, \sim 7 \%, \sim 3 \%, 0 \%$ air saturation).

The maximum theoretical spatial resolution achieved with our imaging system was $\sim 100 \mu \mathrm{m} \times 100 \mu \mathrm{m}$. The detection limit of the optode, determined as three times the standard deviation of the oxygen level measured for an area of $1 \mathrm{~cm}^{2}$ at anoxia, amounted to $1.1 \%$ air saturation, which we define as anoxia.

We combined luminescence lifetime imaging of oxygen with simultaneous time-lapse recordings of the explant osculum. Temporal variations in the osculum cross-sectional area $\left(O S A, \mathrm{~mm}^{2}\right)$, length $(l, \mathrm{~mm})$ and the diameter $(d, \mathrm{~mm})$ of the osculum tube were assessed from top-view time-lapse images (Fig. S1) captured by a digital camera (Canon EOS 1000D) equipped with a macro-lens (Sigma $50 \mathrm{~mm}$ F2.8 EX DG Macro). The camera was synchronized with external blue LED light, and both the camera and light were triggered via a control unit (LED trigger light; Fish ' $n$ ' chips, Germany). Top-view images were recorded every 60-300 s using the image acquisition software Look@RGB (http:// www.fish-n-chips.de/Look@RGB/publish.htm).

\section{Experimental setup}

Experiments were performed with single-osculum explants in fully oxygenated $(0.2 \mu \mathrm{m})$ filtered seawater (salinity of 20) with Rhodomonas salina algal cells added twice per day (Fig. S1). Recirculation and flow of water were provided by an aquarium pump in a $2 \mathrm{~L}$ beaker placed below the excurrent opening of the flume to collect the outflowing water (Fig. S1). A temperature controller maintained a stable water temperature $\left(\mathrm{T}=15.1 \pm 0.2{ }^{\circ} \mathrm{C}\right)$ throughout the experiment. Experiments were performed in darkness to prevent potential impacts of sponge-associated photosynthetic cyanobacteria and algae (Knobloch et al. 2019) on $\mathrm{O}_{2}$ measurements. For 
calibration of $\mathrm{O}_{2}$ images, the oxygen concentration was regulated with a gas mixer (Brooks Instrument, Model 0154) and monitored using a FireSting $\mathrm{O}_{2}$ optical oxygen meter (Pyro Science, Germany) connected to a computer with Pyro Oxygen Logger ${ }^{\circledR}$ software. Oxygen readings were corrected for changes in temperature by the software using an external temperature sensor placed in the flume water.

\section{Image and statistical analysis}

Top-view time-lapse images were analyzed in ImageJ (Version $1.47 \mathrm{~g}$ ). The osculum cross-sectional area (OSA), length $(l)$ and diameter $(d)$ of the osculum tube were manually determined via pixel counts and subsequent conversion into $\mathrm{mm}^{(2)}$ using a reference scale bar. The $O S A$ and $d$ were measured at the tip and at center of the osculum tube, respectively. The $l$ was determined as the distance between tip and base of the oscular tube, while $l=0 \mathrm{~mm}$ represents a fully retracted osculum.

We manually defined the area of the explant base ( $A$, $\mathrm{mm}^{2}$ ) grown on planar optodes in bottom-view images and converted pixel counts into $\mathrm{mm}^{2}$ using a reference scale bar. Bottom-view image sequences were transformed to a 32-bit greyscale format to convert each pixel's brightness/ luminescence signal into an oxygen measurement using the calibration described above. The mean $\mathrm{O}_{2}$ within $A$ of all explants was autonomously measured for each image of the image sequence using the 'multiple measure' function in the ROI manager in ImageJ. Minimum and maximum threshold values were adjusted to determine the (cumulative) relative area of the sponge in various ranges of oxygen levels, i.e. 100 to $80 \%,<80$ to $50 \%,<50$ to $10 \%,<10$ to $1 \%$ and $<1$ to $0 \%$ air saturation. To characterize oxygen dynamics during contraction-expansion events, we calculated the rate of change in oxygen levels ( $\%$ air saturation $\mathrm{min}^{-1}$ ) by substracting the oxygen value $\left(\left[\mathrm{O}_{2}\right]\right)$ from pixels in subsequent images acquired at time $t$, i.e. $\left[\mathrm{O}_{2}\right]_{t}-\left[\mathrm{O}_{2}\right]_{t+1}$, divided by the time difference between images. We determined the mean and the maximal rate of change in oxygen levels during both explant contraction (i.e. $\mathrm{O}_{2}$ decrease) and expansion (i.e. $\mathrm{O}_{2}$ increase).

Statistical analyses were performed in R, version 3.2.0 ( $\mathrm{R}$ Core Team 2015). We tested for differences in time intervals, i.e. time until subsequent deoxygenation/oxygenation events, and their duration, between the sponge indviduals (ID1-ID4) using a generalized linear model (GLM) parameterized with gamma error structure in package lme 4.

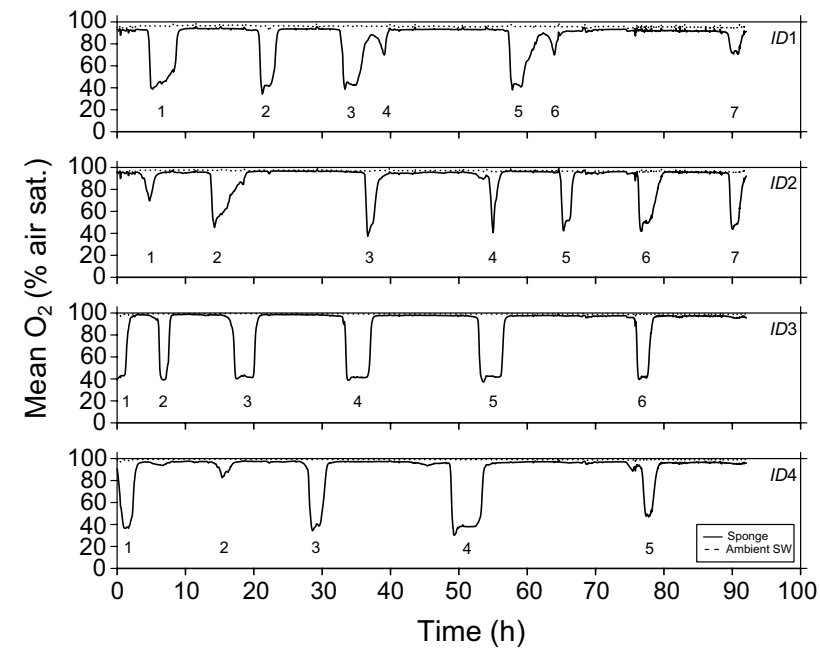

Fig. 2 Mean $\mathrm{O}_{2}$ concentration as a function of time simultaneously measured in the ambient seawater and at the base of single-osculum explants $(I D 1-I D 4)$ on transparent oxygen optodes in a flume with temperature-controlled, oxygenated seawater $\left(15.1^{\circ} \mathrm{C}\right.$, salinity of 20$)$. Legend is shown

\section{Results}

\section{Temporal $\mathbf{O}_{2}$ and osculum dynamics}

Oxygen measured at the base of single-osculum Halichondria panicea explants ( $n=4, I D 1-4)$ approached the levels in the ambient seawater for most, i.e. $78 \pm 3 \%$ of the total observation period of $92 \mathrm{~h}$ (Fig. 2). However, we also observed 25 events with substantial changes in internal $\mathrm{O}_{2}$ in regular as well as irregular intervals (Fig. 2). These oxygen decreases and increases varied in both extent and duration between events and explants (Fig. 2).

We found no significant difference between the four explants in deoxygenation/oxygenation event duration (GLM, $P=0.981$ ) and event time intervals (GLM, $P=0.291$ ) (Tables 1 and S1). We observed, however, occassional apparently synchronized timing in events including the event \#1 in sponge explants $I D 1$ and $I D 2$ and the events \#6 in $I D 2$ and ID3 with \#5 in ID4.

Simultaneous recordings of temporal variations in $\mathrm{O}_{2}$ concentration and sponge osculum dynamics documented that changes in $\mathrm{O}_{2}$ were accompanied by contraction-expansion dynamics in the cross-sectional area (OSA), length $(l)$ and the diameter $(d)$ of the osculum (Fig. 3a). Typically, the contraction-expansion event began with constriction of OSA and $d$, followed by contraction of the oscular tube $(l)$ and subsequent osculum closure, where $O S A=0 \mathrm{~mm}^{2}$. Osculum closure coincided with a rapid decrease in mean $\mathrm{O}_{2}$ concentrations measured at the explant base (Fig. 3b). During inflation of the oscular tube, osculum $l$ and $d$ measurements exceeded those both prior to as well as post osculum closure, 
while the osculum opening remained closed (Fig. 3). Only osculum expansion, i.e. $O S A>0 \mathrm{~mm}^{2}$, was followed by an immediate oxygenation of the explant base, as expressed by an increase in mean $\mathrm{O}_{2}$ until reaching initial levels (Fig. 3b).

\section{Spatial $\mathbf{O}_{2}$ dynamics}

We observed localized oxygen depletion expanding through the explant area over time during osculum closure generating concentric bands of oxygen isopleths, with anoxia (i.e. $<1 \%$ AS) in the middle (Figs. 4, 5). Overall, an oxygen gradient was established with increasing oxygen levels towards the explant edge/circumference. This situation persisted as long as the osculum opening remained contracted (Table 1, Fig. 5). The mean fraction of the explant $A$ 's experiencing anoxia during periods of osculum contraction-expansion varied between $0.01 \%$ (ID2) and $13.2 \%$ (ID3) and was on average $7.4 \pm 4.4 \%$ for all sponge explants (Table 1, Fig. 4).
The duration of sponge anoxia ranged from 0.08 to $4.42 \mathrm{~h}$ (ID4) and was on average $2.0 \mathrm{~h}$.

Oxygenation of the explant base area began with increasing oxygen concentrations at the explant periphery, followed by differential oxygenation of the explant interior, possibly following the water canal system, at least in some cases (e.g. event \#6 in sponge ID3, Fig. 6). We estimated the mean and maximum rate of change in oxygen levels from successive oxygen images during all contraction-expansion events (\#2-\#6). An example for sponge explant ID3 is depicted in Figs. 6, 7. The mean rate of change at the base of this explant ranged from 0 , at the explant periphery, to $4.4 \%$ AS $\min ^{-1}$ and $3.3 \% \mathrm{AS} \mathrm{min}^{-1}$ at the explant interior during contractions and expansions, respectively (Fig. 6). The maximum rates of change in oxygen, as observed within the inner parts of the explant base during the respective contraction-expansion events, ranged from 10.4 to $11.9 \% \mathrm{AS} \mathrm{min}^{-1}$ during contractions, and from 7.0 to $10.6 \% \mathrm{AS} \mathrm{min}^{-1}$ during
Table 1 Events with substantial changes in $\mathrm{O}_{2}$ (\#1 to \#7, Figs. 2, 4) measured at the base of single-osculum $H$. panicea explants (ID1 to $I D 4)$ grown on oxygen-sensitive planar optodes in a flume with $0.2 \mu \mathrm{m}$ filtered seawater and added $R$. salina algae (Fig. S1)

\begin{tabular}{|c|c|c|c|c|c|c|c|}
\hline$I D$ & $\begin{array}{l}\text { Event } \\
\#\end{array}$ & $\begin{array}{l}t \\
(\mathrm{~h})\end{array}$ & $\begin{array}{l}\Delta t_{\text {interval }} \\
\text { (h) }\end{array}$ & $\begin{array}{l}\Delta t \\
(\mathrm{~h})\end{array}$ & $\begin{array}{l}t_{\text {anox }} \\
\text { (h) }\end{array}$ & $\begin{array}{l}\Delta t_{\text {anox }} \\
\text { (h) }\end{array}$ & $\begin{array}{l}A_{\text {anox }} \\
(\%)\end{array}$ \\
\hline \multirow[t]{7}{*}{$I D 1$} & 1 & 4.42 & - & 4.66 & 4.92 & 3.60 & 10.43 \\
\hline & 2 & 20.66 & 16.25 & 3.08 & 21.00 & 2.17 & 11.49 \\
\hline & 3 & 32.58 & 11.92 & 4.58 & 33.08 & 2.75 & 10.92 \\
\hline & 4 & 37.50 & 4.92 & 2.33 & 38.92 & 0.16 & 0.02 \\
\hline & 5 & 57.25 & 19.75 & 4.50 & 57.58 & 2.08 & 11.39 \\
\hline & 6 & 62.83 & 5.58 & 1.75 & - & - & - \\
\hline & 7 & 89.27 & 26.44 & 2.47 & - & - & - \\
\hline \multirow[t]{7}{*}{$I D 2$} & 1 & 3.25 & - & 2.42 & 4.66 & 0.08 & 0.01 \\
\hline & 2 & 13.58 & 10.33 & 5.33 & 14.00 & 3.00 & 3.25 \\
\hline & 3 & 36.08 & 22.50 & 2.33 & 36.58 & 1.33 & 8.98 \\
\hline & 4 & 54.33 & 18.25 & 1.92 & 54.75 & 0.50 & 3.07 \\
\hline & 5 & 64.58 & 10.25 & 2.42 & 65.17 & 1.42 & 5.97 \\
\hline & 6 & 76.19 & 11.61 & 3.77 & 76.41 & 2.70 & 3.80 \\
\hline & 7 & 89.47 & 13.28 & 2.58 & 89.77 & 1.50 & 5.07 \\
\hline \multirow[t]{6}{*}{ ID3 } & 1 & $0^{\mathrm{a}}$ & - & 1.92 & $0^{\mathrm{a}}$ & 1.42 & 10.76 \\
\hline & 2 & 6.00 & 6.00 & 2.17 & 6.25 & 1.25 & 12.91 \\
\hline & 3 & 16.50 & 10.50 & 4.25 & 17.17 & 3.00 & 13.22 \\
\hline & 4 & 33.25 & 16.75 & 4.25 & 33.58 & 3.50 & 12.68 \\
\hline & 5 & 52.75 & 19.50 & 4.00 & 53.17 & 3.33 & 11.83 \\
\hline & 6 & 75.89 & 23.14 & 2.42 & 76.11 & 1.83 & 9.57 \\
\hline \multirow[t]{5}{*}{ ID4 } & 1 & 0 & - & 3.00 & 0.25 & 2.17 & 6.16 \\
\hline & 2 & 14.50 & 14.50 & 2.50 & 15.33 & 0.08 & 0.07 \\
\hline & 3 & 27.83 & 13.33 & 3.08 & 28.17 & 2.33 & 5.89 \\
\hline & 4 & 48.75 & 20.92 & 5.17 & 49.00 & 4.42 & 9.59 \\
\hline & 5 & 76.72 & 27.97 & 2.68 & 77.14 & 1.35 & 4.12 \\
\hline Mean & & & 15.41 & 3.18 & & 2.00 & 7.44 \\
\hline$( \pm \mathrm{SD})$ & & & $( \pm 6.61)$ & $( \pm 1.10)$ & & $( \pm 1.19)$ & $( \pm 4.39)$ \\
\hline
\end{tabular}

$t$ initial time of changes in mean $\mathrm{O}_{2}, \Delta t_{\text {interval }}$ time interval until subsequent change in mean $\mathrm{O}_{2}, \Delta t$ duration of changes in mean $\mathrm{O}_{2}, t_{\text {anox }}$ initial time of anoxia (thus, $O S A=0 \mathrm{~mm}^{2}$, cf. Figure 3), $\Delta t_{\text {anox }}$ duration of anoxia, $A_{\text {anox }}$ mean fraction of sponge area exhibiting anoxia

${ }^{a}$ Minimum value 

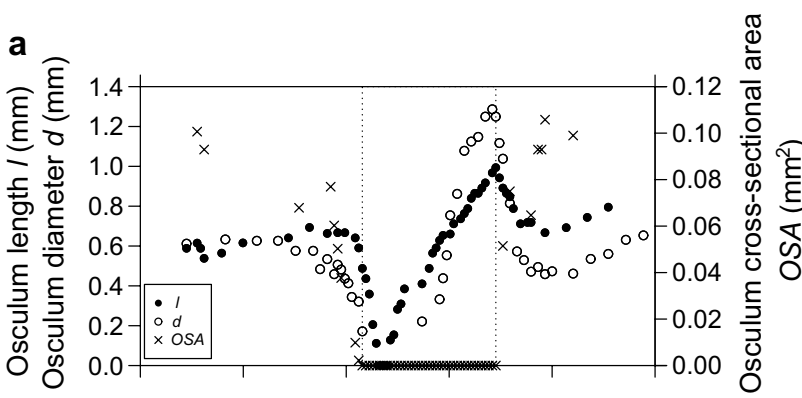

b

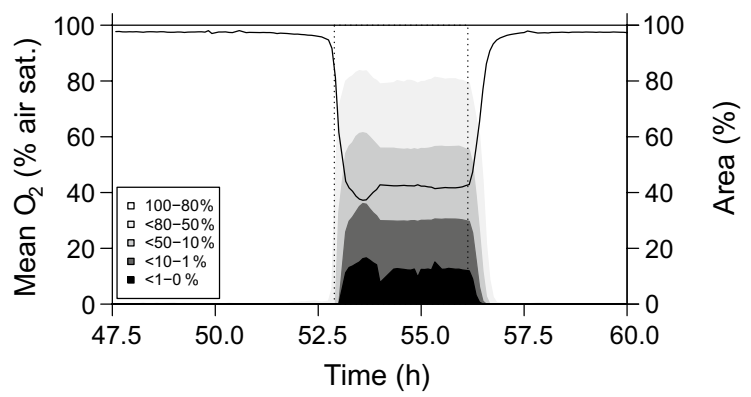

Fig. 3 a Example of temporal changes in osculum length $(l, \mathrm{~mm})$, osculum diameter $(d, \mathrm{~mm})$, osculum cross-sectional area $\left(O S A, \mathrm{~mm}^{2}\right)$ and $\mathbf{b}$ mean $\mathrm{O}_{2}$ level (black line) and cumulative relative area under various oxygen levels (see legend) in a single-osculum explant (ID3) during a contraction-expansion event (\#5). Dashed line indicates period of osculum closure (i.e. $O S A=0 \mathrm{~mm}^{2}$ )

expansions (Fig. 7). Rates of change were not uniform but increased towards the sponge interior (Figs. 6, 7).

\section{Diffusive Oxygen Uptake (DOU)}

To provide a first-order comparison to previous assessments of the $\mathrm{O}_{2}$ consumption rates of sponge explants, we derived the diffusive oxygen uptake $(D O U)$ from concentration profiles extracted from steady-state $\mathrm{O}_{2}$ images of fully contracted explants. For this, we determined the oxygen concentrations along a transect line crossing the sponge area to establish the oxygen gradient (Fig. 5). We then use Fick's first law of diffusion (Jørgensen and Revsbech 1985): $D O U=\phi \times D s \times \partial C / \partial z$, where $\phi$ represents the sponge porosity and $D s$ is the molecular diffusion coefficient of $\mathrm{O}_{2}$ in the sponge corrected for the tortuosity imposed by the sponge spicules where $D s=\phi^{2} \times D$ (Ullman and Aller 1982). In making this tortuosity correction, we assume that sponge spicules impose a restriction to diffusion similar to sediment particles. $D$ is the molecular diffusion coefficient for $\mathrm{O}_{2}$ at the given temperature and salinity (i.e. $1.76 \times 10^{-5} \mathrm{~cm}^{2} \mathrm{~s}^{-1}$; Himmelblau 1964; Broecker and Peng 1974) and $\partial C / \partial z$ represents the $\mathrm{O}_{2}$ gradient. We estimated the sponge porosity from the water content in a $H$. panicea sponge divided by its volume, using the conversion factor from Thomassen and Riisgård (1995): sponge dry weight $(D W, \mathrm{~g})=0.07 V_{\text {sponge }}$. If we assume that most of the $D W$ is due to spicules, which are composed of amorphous opal (with a density of $\sim 2$ ), then the volume of the $D W$ is $0.07 / 2=0.035 \mathrm{~cm}^{3}\left(\mathrm{~cm}^{-3}\right)_{\text {sponge. }}$. Thus, the porosity of our $H$. panicea sponge explants was estimated to be 0.965 .
Fig. 4 Cumulative relative area of the base of single-osculum explants $(I D 1-I D 4)$ in various ranges of oxygen levels (100 to $80 \%,<80$ to $50 \%,<50$ to $10 \%,<10$ to $1 \%$ and $<1$ to $0 \%$ air saturation) measured as a function of time. Legend is shown in the lower panel

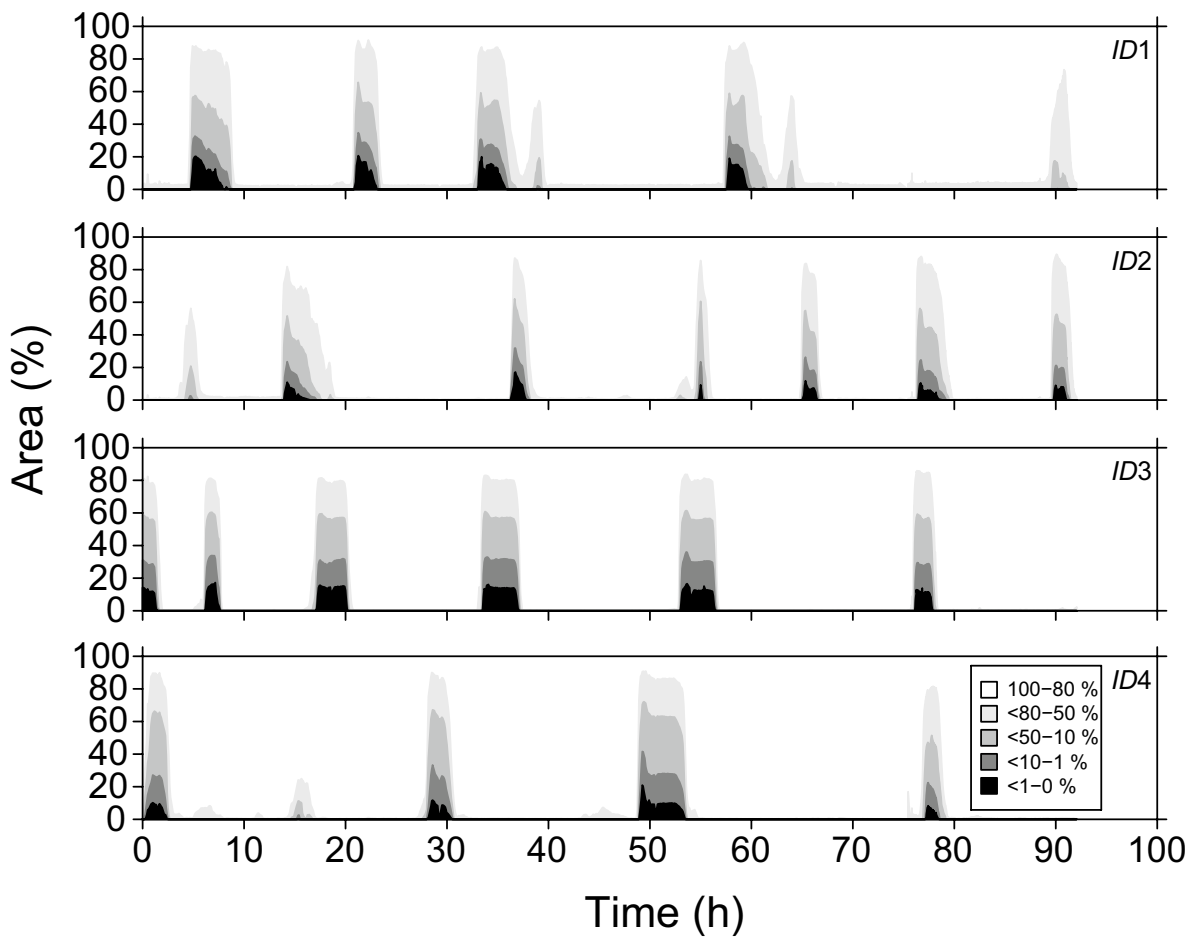


Fig. 5 a Oxygen distribution at the base of a single-osculum explant (ID3) during a contraction-expansion cycle (\#6) in fully oxygenated $(100 \%$ air saturation) ambient seawater (salinity of 20) with R. salina algal cells. Air saturation level is denoted by colour. Black line indicates the contour area (i.e. base) of the sponge grown on the oxygen-sensitive planar optode. b Corresponding oxygen levels (\% air saturation) along a transect (grey dashed line; a) crossing the sponge base (black dashed line; middle panel). Symbols represent individual pixels with a spatial resolution of $100 \times 100 \mu \mathrm{m}$ a

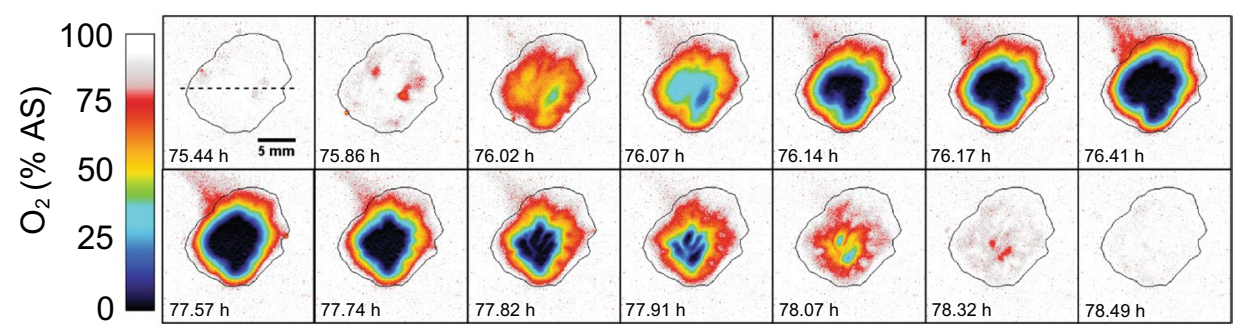

b

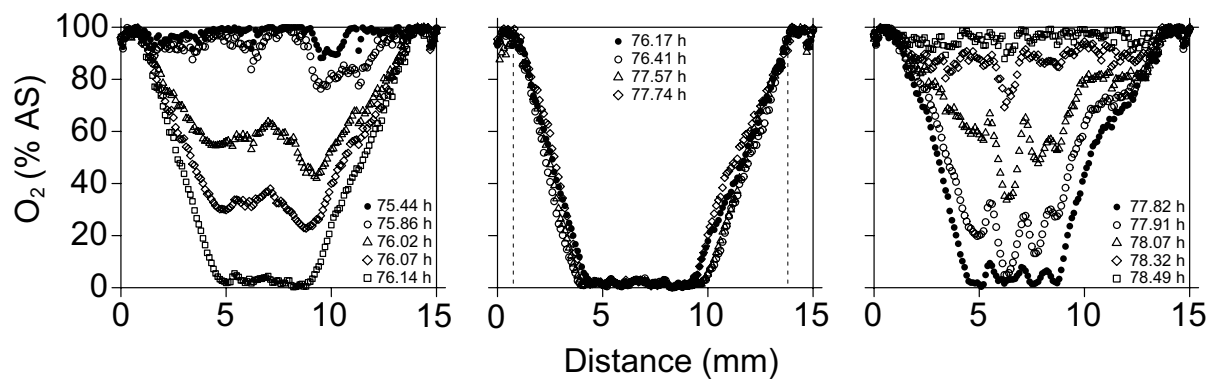

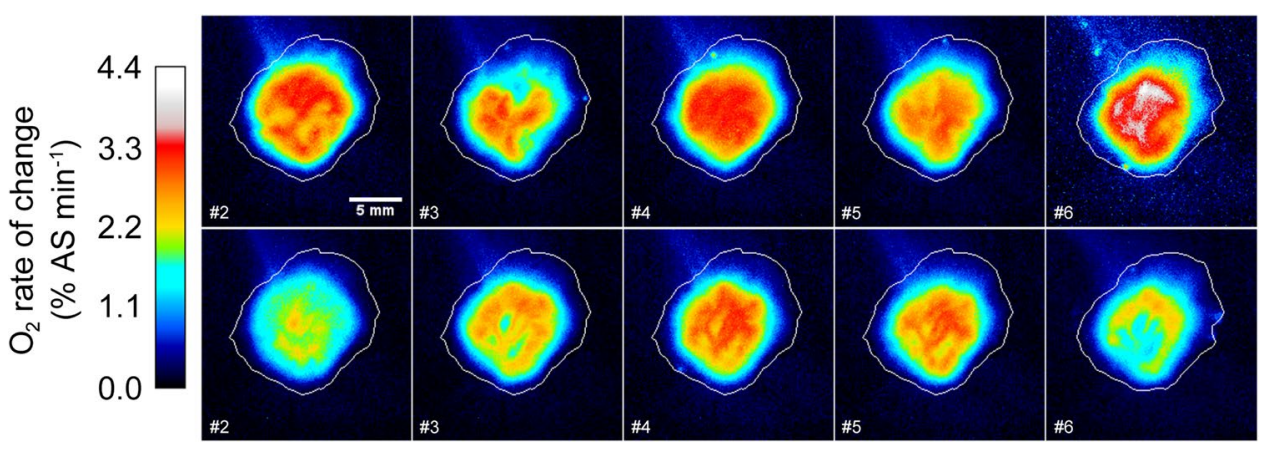

Fig. 6 Mean rate of change in oxygen levels $\left(\% \mathrm{AS} \mathrm{min}^{-1}\right)$ at the base of a single-osculum explant (ID3) during contraction (upper panel)-expansion (lower panel) cycles (\#2 to \#6) in fully oxygenated seawater (salinity of 20 ) with added $R$. salina algal cells. Air satura- tion level is denoted by colour. White line indicates the contour area (i.e. base) of the sponge grown on the oxygen-sensitive planar optode. Pixels contain mean value over all images during contraction-expansion events (\#2 to \#6, Fig. 2)

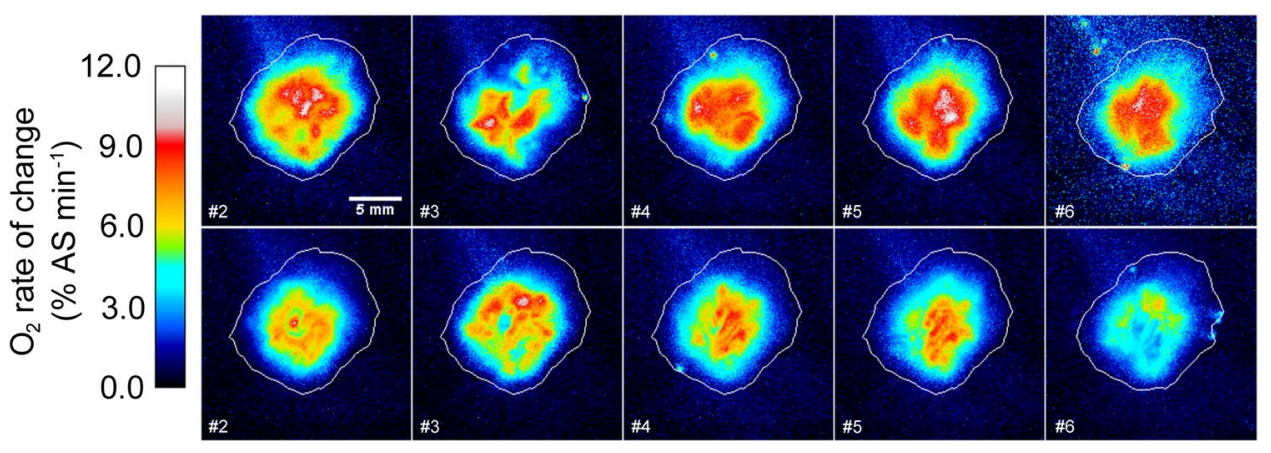

Fig. 7 Maximum rate of change in oxygen levels $\left(\% \mathrm{AS} \mathrm{min}^{-1}\right)$ at the base of a single-osculum explant (ID3) during contraction (upper panel)-expansion (lower panel) cycles (\#2 to \#6) in fully oxygenated seawater (salinity of 20) with added $R$. salina algal cells. Air satura- tion level is denoted by colour. White line indicates the contour area (i.e. base) of the sponge grown on the oxygen-sensitive planar optode. Pixels contain maximal value over all images during contractionexpansion events (\#2 to \#6, Fig. 2) 
The mean DOU $( \pm \mathrm{SD})$ during the recorded 23 periods of osculum closure with anoxia amounted to $1.38 \pm 0.37 \mu \mathrm{mol}$ $\mathrm{O}_{2} \mathrm{~cm}^{-2} \mathrm{~d}^{-1}$. Our oxygen measurements were made at the base of the sponge explant, and if we assume a similar $\mathrm{O}_{2}$ penetration depth and oxygen gradients from the explant surface into its interior for all of the explant body, we can estimate the total diffusion mediated $\mathrm{O}_{2}$ consumption rate of the contracted sponge explant. Thus, for our coneshaped explants with a mean outer respiratory surface area of $1.4 \pm 0.6 \mathrm{~cm}^{2}$, we estimate an integrated $D O U$ of $1.9 \pm 0.8 \mu \mathrm{mol} \mathrm{O}_{2} \mathrm{~d}^{-1}$.

\section{Discussion}

\section{Oxygen dynamics in sponges studied by planar optodes}

This is, to our knowledge, the first record of internal imaging of oxygen dynamics in sponges. Previous studies on demosponges, such as Aplysina aerophoba and Dysidea avara, applied oxygen microsensors for oxygen profiling above and within the sponge tissue to monitor internal and diffusive oxygen fluxes (Hoffmann et al. 2005b, 2008; Schläppy et al. 2007; 2010a; Lavy et al. 2016). While microsensors can indeed record oxygen gradients into the sponge body, they lack 2-D resolution, and temporal dynamics are difficult to record. Furthermore, intrusion of the microsensor may also lead to localized contraction of the water canal system (cf. Prosser et al. 1962; Elliott and Leys 2007), ultimately leading to changes in internal flow regimes which may cause varations in the measured oxygen values (Schoenberg et al. 2004; Schläppy et al. 2007). Planar oxygen-sensitive optodes thereby offer a non-intrusive alternative allowing for both temporal as well spatial oxygen measurements to unravel oxygen dynamics, as previously shown in complex biological samples, such as corals (Kühl et al. 2008), or in benthic environments, such as animal burrows (Wenzhöfer and Glud 2004; Volkenborn et al. 2010).

The observed contraction dynamics in sponges of the present study were similar in duration and periodicity to previous time-lapse observations on H. panicea explants (Kumala et al. 2017; Kumala and Canfield 2018) and other in situ demosponge species, such as Verongia gigantea (Reiswig 1971). Each episode of osculum closure and contraction in our explants was associated with deoxygenation of the explant body (Figs. 2, 3, 5) as was predicted from respiration rate measurements during periods of pumping cessation by Kumala and Canfield (2018). The current study demonstrates that isopleths of oxygen concentration were approximately concentric around the explant interior and only the innermost part of the sponge explant experienced complete anoxia during periods of osculum closure.
The area (and presumably also volume) of the explant experiencing anoxia $\left(\mathrm{O}_{2}<1 \%\right.$ PAL) was relatively small during osculum contraction-expansion $(7.4 \pm 4.4 \%$ for all our sponge explants; Table 1, Fig. 4). In contrast, the rates of oxygen respiration, as approximated by the rate of change of oxygen concentration during sponge deoxygenation (Figs. 6, 7) were relatively similar through most of the explant base area. To fully quantify the $\mathrm{O}_{2}$ consumption rates and dynamics of the contracted explants, we would need to resolve the 3-D $\mathrm{O}_{2}$ distribution and diffusion geometry of the explants (Meysman et al. 2010). Our simplified approach for assessing the $\mathrm{O}_{2}$ consumption from planar (i.e. flat plane) images that only cover the base of the explant neglects potential geometric (i.e. curvature) effects on diffusive fluxes at the external exopinacodermal sponge-seawater interface. Furthermore, we assume that our estimate of the $\mathrm{O}_{2}$ penetration depth and consumption derived at the explant base is representative of the entire explant. The patterns of $\mathrm{O}_{2}$ distribution observed at the base of our explants appear to be similar to those measured through the outer surfaces of non-pumping demosponges investigated using $\mathrm{O}_{2}$ microsensors (Fig. 5; Schläppy et al. 2007, 2010a; Hoffmann et al. 2008). Also, our estimate of the integrated diffusive oxygen uptake rate of $1.9 \pm 0.8 \mu \mathrm{mol} \mathrm{O} \mathrm{O}_{2} \mathrm{~d}^{-1}$ across the entire sponge explant surface is in accordance with the oxygen consumption rate of $1.1 \pm 0.3 \mu \mathrm{mol} \mathrm{O} \mathrm{O}^{-1}$ measured during incubation experiments with (non-pumping) $\mathrm{H}$. panicea explants of comparable size (Kumala and Canfield 2018). This similarity reinforces the idea that respiration is limited by the diffusive flux across the outer sponge surface during periods of osculum closure (Hoffmann et al. 2008; Kumala and Canfield 2018).

We observed that oxygenation of the explant interior tended to occur in canal-like structures of 100-300 $\mu \mathrm{m}$ diameter pervading the concentrical anoxic area (Figs. 5, 6, 7). Contractile behaviour of the osculum is associated with contraction-expansion of the internal water canal system in these single-osculum $H$. panicea explants (cf. Kumala et al. 2017; Goldstein et al. 2020), as well as in other demosponge species, such as Ephydatia muelleri and Tethya wilhelma (Elliott and Leys 2007; Ellwanger et al. 2007; Nickel et al. 2011). During reoxygenation, we observed the deep penetration of oxygenated water into the sponge explant through pumping. We also note that rates of deoxygenation were faster than rates of reoxygenation of the sponge explant, which is explained by the fact that the $\mathrm{O}_{2}$ decrease in the explant interior during full contraction is driven by respiration, while the oxygen increase during expansion is affected by both, ongoing respiration and advective water transport through the aquiferous system. 


\section{Regulation of internal $\mathrm{O}_{2}$ dynamics}

Our findings visually demonstrate that internal oxygen dynamics in $H$. panicea demosponge explants are driven by their contractile behaviour, which includes considerable fluctuations in oxygen levels in major parts of the sponge explant body. As noted above, for most of the observation time, our single-osculum $H$. panicea explants revealed internal oxygen levels approaching that of the ambient seawater (Figs. 2, 4). Therefore, during periods of maximal pumping activity, the advective flux through the internal water canal system saturates the explant interior with oxygen, thus providing ample oxygen to respiring sponge cells and the internal microbiome.

In $H$. panicea sponge explants, osculum closure is linked to a considerable compression of aquiferous space including the in-/excurrent canals and water-pumping choanocyte chambers (Goldstein et al. 2020), eliminating internal water flow (Kumala et al. 2017; Goldstein et al. 2019). These periods of pumping cessation result in a gradual depletion of oxygen reserves in the sponge interior by respiration (Hazelhoff 1938; Kumala and Canfield 2018). At steady state, molecular diffusion of oxygen across the outer-explant body remains the only mechanism for oxygen supply to the explant tissue (Fig. 5; Hoffmann et al. 2005a, b, 2008; Schläppy et al. 2007, 2010a; Kumala and Canfield 2018). The diffusive oxygen uptake (DOU) of $1.4 \pm 0.4 \mu \mathrm{mol} \mathrm{O}$ $\mathrm{cm}^{2} \mathrm{~d}^{-1}$ by contracted $H$. panicea sponge explants in the present experiments is in the lower range of those determined from oxygen profile measurements using oxygen-sensitive microsensors across the exopinacoderm in other (non-pumping) demosponges, such as Aplysina aerophoba (Hoffmann et al. 2005a, 2008; Schläppy et al. 2007). In A. aerophoba and Dysidea avara, for instance, rates of oxygen uptake of 4.5-4.7 $\mu \mathrm{mol} \mathrm{O} \mathrm{cm}^{-2} \mathrm{~d}^{-1}$ and $4.2 \mu \mathrm{mol} \mathrm{O}_{2} \mathrm{~cm}^{-2} \mathrm{~d}^{-1}$, respectively, were measured during pumping cessation. The lower $D O U$ in our H. panicea explants may be explained by possible differences in the distribution of structural elements, porosity and sponge tissues which can strongly vary among sponge species. In fact, oxygen consumption/uptake rates in sponges generally appear to be species-specific and may additionally be influenced by the temperature conditions used in laboratory experiments (Osinga et al. 1999).

It is not clear to what extent our observations on single-osculum explants can be applied to sponges in general, particularly to those with multiple exhalant openings, i.e. oscula. However, if we view water canal systems within sponges as individual aquiferous modules (Frey 1970, 1979; Ereskovskii 2003), with advective water output through an osculum opening, then it would stand to reason that oscula closure (or contraction of various parts of the aquiferous system, e.g. inhalant pores) would encourage deoxygenation of the sponge interior. If this is true, internal sponge anoxia might be common, but not necessarily synchronous through the whole sponge body. If individual water canal systems are not coupled and oscula closing is non-synchronous, as observed in multi-oscula $H$. panicea sponges (Riisgård et al. 2016), then some parts of the sponge body may experience anoxia while other parts are fully oxygenated. We observed localized oxygen depletion that expanded throughout the sponge explant (Fig. 5), indicating that single-osculum sponges may regulate oxygen even in specific parts of the sponge interior which could result in heterogenous oxygenation of sponge tissue. However, if water can be actively advected through the pinacoderm of a more porous sponge (Gatti et al. 2002; Schläppy et al. 2010a), then internal anoxia may not be achieved. For instance, primmorphs of the demosponge Suberites domuncula, in which internal structures have not yet developed, solely depend on advective water flow to oxygenate their interior (Gatti et al. 2002).

\section{Implications of contractile behaviour and subsequent oxygen dynamics}

The observed contractile behaviour and subsequent changes in $\mathrm{O}_{2}$ level in the sponge interior may strongly affect sponge metabolism and the activity of the highly diverse microbial consortia in sponges. Irregular, as well as regular, contraction-expansion of compartments of the water canal system (ostia, water canals and oscula) in response to disturbances (e.g. agitation, Elliot and Leys 2007), or as part of their natural behaviour (Reiswig 1971), may influence filter-feeding (Kumala et al. 2017) and the internal redox state. To our knowledge, sponges lack the ability for anaerobic metabolism but are host to functional microbes that are capable of mediating nutrient cycling during periods of internal anoxia (reviewed in Zhang et al. 2019). Aerobic and anaerobic processes have been detected in both high microbial abundance (HMA) and low microbial abundance (LMA) sponges (Schläppy et al. 2010b). For instance, nitrification, denitrification and anaerobic ammonia oxidation ('anammox') may occur in the HMA sponge Geodia baretti (Hoffmann et al. 2009), highlighting the benefit of coupled aerobic and anaerobic niches for nutrient cycling within the sponge holobiont. Spatial and temporal oxygen depletion in the sponge body, as observed in our explants and other sponge species (Hoffmann et al. 2005a, 2008; Schläppy et al. 2010a), may maintain and regulate the activity of the sponge microbiome, removing toxic metabolic waste (e.g. ammonium) produced by the sponge during active filter-feeding and digestion (cf. Kumala and Canfield 2018; Hudspith et al. 2021). Contractile behaviour, and subsequent pumping cessation, may hence be considered as a nutrient conserving mechanism that limits nutrient loss to mediate mutualistic relationships between sponges and their microbiomes (Hudspith et al. 2021). 
The shifting redox state in the sponge interior, in response to changing pumping dynamics, may favour the abundance and distinct distribution of functional microbial groups according to their metabolic oxygen requirements. Distinct bacterial phylotypes involved in nutrient cycling may occur in varying numbers in different sections of the sponge body (Thiel et al. 2007; Yang and Li 2012; but see Sipkema and Blanch 2010), which can also be hotspots for metabolic activity. In the intertidal demosponge Cinachyrella cavernosa, for instance, active nitrifiers were found to be abundantly located in the sponge cortex where 2 times higher nitrification rates were detected compared to intraor extracellular sections of the sponge specimen (Subina et al. 2018). We hypothesize that both anaerobic as well as facultative anaerobic microbes are likely to occur in areas that regularly experience anoxia during osculum contraction, such as the concentrical anoxic area, as observed in our explants. Conversely, obligate and facultative aerobic microorganisms may be closely associated with (outer) regions of the sponge (e.g. cortex/exopinacoderm), that are sufficiently supplied with oxygen during periods of pumping cessation. The active 'control' of internal shifting between oxygen levels via contractile behaviour may also enable sponges to maintain or 'farm' distinct microbes ('bacterial farming'), as suggested for $H$. panicea (Knobloch et al. 2019) and other demosponge species that exhibit varying internal oxygen levels, such as Theonella swinhoei (Lavy et al. 2016). $H$. panicea sponges from Icelandic waters, for instance, are hosts for a dominant and temporally-stable alphaproteobacterium ('Candidatus Halichondribacter symbioticus'; Knobloch et al. 2019), whose draft gene repertoire points towards the dynamic exchange of metabolites between this symbiont and the sponge-host environment, including ammonia assimilation or the production of a putative bacteriocin (Knobloch et al. 2020).

\section{Perspective}

Our study demonstrates that modular luminescence lifetime imaging is well suited to investigate 2-dimensional and temporal oxygen dynamics in sponges. Shifting oxygen levels in the sponge mesohyl, as observed in the present study, reflect a combination of effects from changes in the sponge host pumping activity and internal respiration by both sponge cells and microbial cells. We found that contraction of the sponge osculum leads to concentrical anoxia in the innermost part of the sponge explant and an oxygen gradient with increasing oxygen levels towards the explant circumference. Our findings support a previous hypothesis that the subsequent diffusive flux of oxygen across the pinacoderm of $H$. panicea explants facilitates oxygenation of major parts of sponge tissue during non-pumping periods
(Kumala and Canfield 2018). We hypothesize that contraction of select compartments of the aquiferous system may enable sponges to regulate oxygen in specific parts of the sponge interior, which may result in heterogenous oxygenation of sponge tissue. Spatial and temporal shifting between internal oxygen levels may facilitate distinct microbes to colonize niches in the sponge interior according to their metabolic oxygen requirements, enabling intertwined metabolic networking between sponges and their internal microbiomes. New 3-dimensional $\mathrm{O}_{2}$ measuring approaches, such as $\mathrm{O}_{2}$-sensitive nanoparticles (Koren et al. 2016; Brodersen et al. 2020), combined with the laser-induced fluorescence techniques (Murniati et al. 2016, 2017), could facilitate the 3-D mapping of $\mathrm{O}_{2}$ around sponges and even in the interior of a transparent sponge. This would enable a holistic assessment of $\mathrm{O}_{2}$ consumption and subsequent fluxes across external as well as internal sponge-seawater interfaces, complementing the temporal and spatial oxygen dynamics revealed in the present study.

Supplementary Information The online version contains supplementary material available at https://doi.org/10.1007/s00227-021-03980-2.

Acknowledgements We thank Anni Glud for technical assistance with the experimental setup, Astrid Schuster for help with schematic illustrations and Brian Strehlow for proofreading. We also thank the reviewers who provided constructive comments to improve an earlier draft of this article. This work was supported by a Villum grant (Grant No. 16518), and by HADES-ERC Advanced Grant (No. 669947), the Danish National Research Foundation through the Danish Center for Hadal Research, HADAL (No. DNRF145).

Author contributions All authors contributed to the concept and design of the study. Biological materials and sensors were prepared by L. Kumala and M. Larsen. Data collection and analysis were performed by L. Kumala. The first draft of the manuscript was written by L. Kumala and D.E. Canfield. All authors commented and edited on subsequent versions of the manuscript. All authors read and approved the final version of the manuscript.

Funding This study was supported by a Villum grant (Grant No. 16518), and by HADES-ERC Advanced Grant (No. 669947), the Danish National Research Foundation through the Danish Center for Hadal Research, HADAL (No. DNRF145).

Data availability The datasets generated and/or analysed during the current study are available from the corresponding author on reasonable request.

Code availability Not applicable.

\section{Declarations}

Conflict of interest The authors have no conflict of interests to declare that are relevant to the content of this article.

Ethics approval No approval of research ethics committees was required to accomplish the goals of this study because experimental work was conducted with an unregulated invertebrate species. 
Open Access This article is licensed under a Creative Commons Attribution 4.0 International License, which permits use, sharing, adaptation, distribution and reproduction in any medium or format, as long as you give appropriate credit to the original author(s) and the source, provide a link to the Creative Commons licence, and indicate if changes were made. The images or other third party material in this article are included in the article's Creative Commons licence, unless indicated otherwise in a credit line to the material. If material is not included in the article's Creative Commons licence and your intended use is not permitted by statutory regulation or exceeds the permitted use, you will need to obtain permission directly from the copyright holder. To view a copy of this licence, visit http://creativecommons.org/licenses/by/4.0/.

\section{References}

Borisov SM, Klimant I (2007) Ultrabright oxygen optodes based on cyclometalated iridium (III) coumarin complexes. Anal Chem 79:7501-7509

Brill B (1973) Untersuchungen zur Ultrastruktur der Choanocyte von Ephydatia fluviatilis L. Z Zellforsch Mikrosk Anat 144:231-245

Brodersen KE, Kühl M, Trampe E, Koren K (2020) Imaging $\mathrm{O}_{2}$ dynamics and microenvironments in the seagrass leaf phyllosphere with magnetic optical sensor nanoparticles. Plant J 104:1504-1519

Broecker WS, Peng TH (1974) Gas exchange rates between air and sea. Tellus 26:21-35

Corredor JE, Wilkinson CR, Vicente VP, Morell JM, Otero E (1988) Nitrate release by Caribbean reef sponges. Limnol Oceanogr 33:114-120

de Goeij JM, Lesser MP, Pawlik JR (2017) Nutrient fluxes and ecological functions of coral reef sponges in a changing ocean. In: Carballo J, Bell J (eds) Climate change, ocean acidification and sponges. Springer International Publishing, Switzerland, pp 373-410

DeGraff BA, Demas JN (2005) Luminescence-based oxygen sensors. In: Geddes CD, Lakowicz JR (eds) Reviews in fluorescence. Springer, New York, pp 125-151

Elliott GR, Leys SP (2007) Coordinated contractions effectively expel water from the aquiferous system of a freshwater sponge. J Exp Biol 210:3736-3748

Ellwanger K, Eich A, Nickel M (2007) GABA and glutamate specifically induce contractions in the sponge Tethya wilhelma. J Comp Physiol A 193:1-11

Engelberts JP, Robbins SJ, de Goeij JM, Aranda M, Bell SC, Webster NS (2020) Characterization of a sponge microbiome using an integrative genome-centric approach. ISME J 14:1100-1110

Ereskovskii AV (2003) Problems of coloniality, modularity, and individuality in sponges and special features of their morphogenesis during growth and asexual reproduction. Russ J Mar Biol 29:4656. https://doi.org/10.1023/B:RUMB.0000011716.90730.ac

Fischer JP, Wenzhoefer F (2010) A novel planar optode setup for concurrent oxygen and light field imaging: application to a benthic phototrophic community. Limnol Oceanogr-Meth 8:254-268. https://doi.org/10.4319/lom.2010.8.254

Fjerdingstad EJ (1961) The ultrastructure of choanocyte collars in Spongilla lacustris (L.). Z Zellforsch Mikrosk Anat 53:645-657

Frederiksen MS, Glud RN (2006) Oxygen dynamics in the rhizosphere of Zostera marina: a two-dimensional planar optode study. Limnol Oceanogr 51:1072-1083

Fry WG (1970) The sponge as a population: a biometric approach. In: Fry WG (ed) The biology of the Porifera. Academic Press, London, pp 135-162
Fry WG (1979) Taxonomy, the individual and the sponge. In: Rosen B, Larwood G (eds) Biology and systematics of colonial organisms. Academic Press, London, pp 49-80

Gaino E, Pansini M, Pronzato R, Cicogna F (1991) Morphological and structural variations in Clathrina clathrus (Porifera, Calcispongiae). In: Reitner J, Keupp H (eds) Fossil and recent sponges. Springer-Verlag, Berlin-Heidelberg, pp 360-371

Gatti S, Brey T, Müller W, Heilmayer O, Holst G (2002) Oxygen microoptodes: a new tool for oxygen measurements in aquatic animal ecology. Mar Biol 140:1075-1085

Glud RN, Ramsing NB, Gundersen JK, Klimant I (1996) Planar optrodes: a new tool for fine scale measurements of two dimensional $\mathrm{O}_{2}$ distribution in benthic communities. Mar Ecol Prog Ser 140:217-226

Glud RN, Santegoeds CM, De Beer D, Kohls O, Ramsing NB (1998) Oxygen dynamics at the base of a biofilm studied with planar optodes. Aquat Microb Ecol 14:223-233

Glud RN, Wenzhöfer F, Tengberg A, Middelboe M, Oguri K, Kitazato $\mathrm{H}$ (2005) Distribution of oxygen in surface sediments from central Sagami Bay, Japan: In situ measurements by microelectrodes and planar optodes. Deep Sea Res I 52:1974-1987

Goldstein J, Riisgård HU, Larsen PS (2019) Exhalant jet speed of single-osculum explants of the demosponge Halichondria panicea and basic properties of the sponge-pump. J Exp Mar Biol Ecol 511:82-90

Goldstein J, Bisbo N, Funch P, Riisgård HU (2020) Contraction-expansion and the effects on the aquiferous system in the demosponge Halichondria panicea. Front Mar Sci 7:113

Hazelhoff EH (1938) Über die Ausnutzung des Sauerstoffs bei verschiedenen Wassertieren. Z Vergl Physiol 26:306-327

Himmelblau DM (1964) Diffusion of dissolved gases in liquids. Chem Rev 64:527-550

Hoer DR, Tommerdahl JP, Lindquist NL, Martens CS (2018) Dissolved inorganic nitrogen fluxes from common Florida Bay (USA) sponges. Limnol Oceanogr 63:2563-2578

Hoer DR, Sharp W, Delgado G, Lindquist NL, Martens CS (2020) Sponges represent a major source of inorganic nitrogen in Florida Bay (USA). Limnol Oceanogr 65:1235-1250

Hoffmann F, Larsen O, Thiel V, Rapp HT, Pape T, Michaelis W, Reitner J (2005a) An anaerobic world in sponges. Geomicrobiol J 22:1-10

Hoffmann F, Larsen O, Rapp HT, Osinga R (2005b) Oxygen dynamics in choanosomal sponge explants. Mar Biol Res 1:160-163. https:// doi.org/10.1080/17451000510019006

Hoffmann F, Røy H, Bayer K, Hentschel U, Pfannkuchen M, Brümmer F, De Beer D (2008) Oxygen dynamics and transport in the Mediterranean sponge Aplysina aerophoba. Mar Biol 153:1257-1264

Hoffmann F, Radax R, Woebken D, Holtappels M, Lavik G, Rapp HT, Hoffmann SML, Schleper C, Kuypers MM (2009) Complex nitrogen cycling in the sponge Geodia barretti. Environ Microbiol 11:2228-2243

Holst G, Grunwald B (2001) Luminescence lifetime imaging with transparent oxygen optodes. Sensors Actuat B-Chem 74:78-90

Holst G, Kohls O, Klimant I, König B, Kühl M, Richter T (1998) A modular luminescence lifetime imaging system for mapping oxygen distribution in biological samples. Sensors Actuat B-Chem $51: 163-170$

Hudspith M, Rix L, Achlatis M, Bougoure J, Guagliardo P, Clode PL, Webster NS, Muyzer G, Pernice M, de Goeij JM (2021) Subcellular view of host-microbiome nutrient exchange in sponges: insights into the ecological success of an early metazoan-microbe symbiosis. Microbiome 9:1-15

Jones WC (1962) Is there a nervous system in sponges? Biol Rev Camb Philos Soc 37:1-50. https://doi.org/10.1111/j.1469-185X.1962. tb01602.x 
Jørgensen BB, Revsbech NP (1985) Diffusive boundary layers and the oxygen uptake of sediments and detritus. Limnol Oceanogr 30:111-122

Keesing JK, Strzelecki J, Fromont J, Thomson D (2013) Sponges as important sources of nitrate on an oligotrophic continental shelf. Limnol Oceanogr 58:1947-1958

Kilian EF (1952) Wasserströmung und Nahrungsaufnahme beim Süsswasserschwamm Ephydatia fluviatilis. Z Vgl Physiol 34:407-447

Klimant I, Meyer V, Kühl M (1995) Fiber-optic oxygen microsensors, a new tool in aquatic biology. Limnol Oceanogr 40:1159-1165

Knobloch S, Jóhannsson R, Marteinsson V (2019) Bacterial diversity in the marine sponge Halichondria panicea from Icelandic waters and host-specificity of its dominant symbiont "Candidatus Halichondribacter symbioticus". FEMS Microbiol Ecol 95:fiy220

Knobloch S, Jóhannsson R, Marteinsson VP (2020) Genome analysis of sponge symbiont 'Candidatus Halichondribacter symbioticus' shows genomic adaptation to a host-dependent lifestyle. Environ Microbiol 22:483-498

Koren K, Jakobsen SL, Kühl M (2016) In-vivo imaging of $\mathrm{O}_{2}$ dynamics on coral surfaces spray-painted with sensor nanoparticles. Sens Actuators B Chem 237:1095-1101

Kühl M, Rickelt LF, Thar R (2007) Combined imaging of bacteria and oxygen in biofilms. Appl Environ Microbiol 73:6289-6295

Kühl M, Holst G, Larkum AW, Ralph PJ (2008) Imaging of oxygen dynamics within the endolithic algal community of the massive coral Porites lobata. J Phycol 44:541-550

Kumala L, Canfield DE (2018) Contraction dynamics and respiration of small single-osculum explants of the demosponge Halichondria panicea. Front Mar Sci 5:410

Kumala L, Riisgård HU, Canfield DE (2017) Osculum dynamics and filtration activity in small single-osculum explants of the demosponge Halichondria panicea. Mar Ecol Progr Ser 572:117-128

Larsen PS, Riisgåd HU (1994) The sponge pump. J Theor Biol 168:53-63

Larsen M, Borisov SM, Grunwald B, Klimant I, Glud RN (2011) A simple and inexpensive high resolution color ratiometric planar optode imaging approach: application to oxygen and $\mathrm{pH}$ sensing. Limnol Oceanogr-Meth 9:348-360

Larsen M, Santner J, Oburger E, Wenzel WW, Glud RN (2015) $\mathrm{O}_{2}$ dynamics in the rhizosphere of young rice plants (Oryza sativa L.) as studied by planar optodes. Plant Soil 390:279-292

Lavy A, Keren R, Yahel G, Ilan M (2016) Intermittent hypoxia and prolonged suboxia measured in situ in a marine sponge. Front Mar Sci 3:263

Leys SP, Yahel G, Reidenbach MA, Tunnicliffe V, Shavit U, Reiswig HM (2011) The sponge pump: the role of current induced flow in the design of the sponge body plan. PLOS ONE 6:e27787

Lurgi M, Thomas T, Wemheuer B, Webster NS, Montoya JM (2019) Modularity and predicted functions of the global sponge-microbiome network. Nat Commun 10:1-12

Meysman FJ, Galaktionov OS, Glud RN, Middelburg JJ (2010) Oxygen penetration around burrows and roots in aquatic sediments. J Mar Res 68:309-336

Mills DB, Francis WR, Vargas S, Larsen M, Elemans CP, Canfield DE, Wörheide G (2018) The last common ancestor of animals lacked the HIF pathway and respired in low-oxygen environments. Elife 7:e31176

Moitinho-Silva L, Nielsen S, Amir A, Gonzalez A, Ackermann GL, Cerrano C, Astudillo-Garcia C, Easson C, Sipkema D, Liu F, Steinert G, Kotoulas G, McCormack GP, Feng G, Bell JJ, Vicente J, Björk JR, Montoya JM, Olson JB, Reveillaud J, Steindler L, Pineda MC, Marra MV, Ilan M, Taylor MW, Polymenakou P, Erwin PM, Schupp PJ, Simister RL, Knight R, Thacker RW, Costa R, Hill RT, Lopez-Legentil S, Dailianis T, Ravasi T, Hentschel U, Li Z, Webster NS, Thomas T (2017) The sponge microbiome project. Gigascience 6:077
Murniati E, Gross D, Herlina H, Hancke K, Glud RN, Lorke A (2016) Oxygen imaging at the sediment-water interface using lifetimebased laser induced fluorescence ( $\tau$ LIF) of nano-sized particles. Limnol Oceanogr-Meth 14:506-517

Murniati E, Gross D, Herlina H, Hancke K, Lorke A (2017) Effects of bioirrigation on the spatial and temporal dynamics of oxygen above the sediment-water interface. Freshw Sci 36:784-795

Nickel M, Donath T, Schweikert M, Beckmann F (2006) Functional morphology of Tethya species (Porifera): 1. Quantitative 3D-analysis of Tethya wilhelma by synchrotron radiation based X-ray microtomography. Zoomorphology 125:209-223

Nickel M, Scheer C, Hammel JU, Herzen J, Beckmann F (2011) The contractile sponge epithelium sensu lato-body contraction of the demosponge Tethya wilhelma is mediated by the pinacoderm. $\mathrm{J}$ Exp Biol 214:1692-1698

Osinga R, Tramper J, Wijffels RH (1999) Cultivation of marine sponges. Mar. Biotechnol 1:509-532

Pavans de Ceccatty M (1974) Coordination in sponges. The foundations of integration. Am Zool 14:895-903. https://doi.org/10. 1093/icb/14.3.895

Pavans de Ceccatty M (1986) Cytoskeletal organization and tissue patterns of epithelia in the sponge Ephydatia mülleri. J Morphol 189:45-65

Pavans de Ceccatty M (1989) Les éponges, à l'aube des communications cellulaires. Pour Sci 142:64-72

Prest EI, Staal M, Kühl M, van Loosdrecht MCM, Vrouwenvelder JS (2012) Quantitative measurement and visualization of biofilm O2 consumption rates in membrane filtration systems. J Membrane Sci 392:66-75

Prosser CL, Nagai T, Nystrom RA (1962) Oscular contractions in sponges. Comp Biochem Physiol 6:69-74. https://doi.org/10. 1016/0010-406X(62)90044-0

R Core Team (2015) R: A language and environment for statistical computing. R Foundation for Statistical Computing, Vienna

Reiswig HM (1971) In situ pumping activities of tropical Demospongiae. Mar Biol 9:38-50. https://doi.org/10.1007/BF00348816

Riisgård HU, Kumala L, Charitonidou K (2016) Using the F/R-ratio for an evaluation of the ability of the demosponge Halichondria panicea to nourish solely on phytoplankton versus free-living bacteria in the sea. Mar Biol Res 12:907-916

Schläppy ML, Hoffmann F, Røy H, Wijffels RH, Mendola D, Sidri M, De Beer D (2007) Oxygen dynamics and flow patterns of Dysidea avara (Porifera: Demospongiae). J Mar Biol Assoc UK 87:1677-1682

Schläppy ML, Weber M, Mendola D, Hoffmann F, De Beer D (2010a) Heterogeneous oxygenation resulting from active and passive flow in two Mediterranean sponges, Dysida avara and Chondrosia reniformis. Limnol and Oceanogr 55:1289-1300

Schläppy ML, Schöttner SI, Lavik G, Kuypers MM, de Beer D, Hoffmann F (2010b) Evidence of nitrification and denitrification in high and low microbial abundance sponges. Mar Biol 157:593602. https://doi.org/10.1007/s00227-009-1344-5

Schönberg CHL, Hoffmann F, Gatti S (2004) Using microsensors to measure sponge physiology. Bollettino Dei Musei e Degli Istituti Biologici Dell' Universitá Die Genova 68:593-604

Sipkema D, Blanch HW (2010) Spatial distribution of bacteria associated with the marine sponge Tethya californiana. Mar Biol 157:627-638

Southwell MW, Popp BN, Martens CS (2008) Nitrification controls on fluxes and isotopic composition of nitrate from Florida Keys sponges. Mar Chem 108:96-108

Staal M, Borisov SM, Rickelt LF, Klimant I, Kühl M (2011) Ultrabright planar optodes for luminescence life-time based microscopic imaging of $\mathrm{O} 2$ dynamics in biofilms. J Microbiol Methods 85:67-74 
Strehlow BW, Jorgensen D, Webster NS, Pineda MC, Duckworth A (2016) Using a thermistor flowmeter with attached video camera for monitoring sponge excurrent speed and oscular behaviour. Peer J 4:e2761. https://doi.org/10.7717/peerj.2761

Subina NS, Thorat BR, Gonsalves MJ (2018) Nitrification in intertidal sponge Cinachyrella cavernosa. Aquat Ecol 52:155-164

Taylor MW, Radax R, Steger D, Wagner M (2007) Sponge-associated microorganisms: evolution, ecology, and biotechnological potential. Microbiol Mol Biol Rev 71:295-347

Thiel V, Neulinger SC, Staufenberger T, Schmaljohann R, Imhoff JF (2007) Spatial distribution of sponge-associated bacteria in the Mediterranean sponge Tethya aurantium. FEMS Microbiol Ecol 59:47-63

Thomas T, Moitinho-Silva L, Lurgi M, Björk JR, Easson C, Astudillo-García C, Olson JB, Erwin PM, López-Legentil S, Luter H, Chaves-Fonnegra A, Costa R, Schupp PJ, Steindler L, Erpenbeck D, Gilbert J, Knight R, Ackermann G, Lopez JV, Taylor MW, Thacker RW, Montoya JM, Hentschel U, Webster NS (2016) Diversity, structure and convergent evolution of the global sponge microbiome. Nat Commun. https://doi.org/10.1038/ncomms11870

Thomassen S, Riisgård HU (1995) Growth and energetics of the sponge Halichondria panicea. Mar Ecol Prog Ser 128:239-246

Ullman WJ, Aller RC (1982) Diffusion coefficients in nearshore marine sediments 1. Limnol Oceanogr 27:552-556
Volkenborn N, Polerecky L, Wethey DS, Woodin SA (2010) Oscillatory porewater bioadvection in marine sediments induced by hydraulic activities of Arenicola marina. Limnol Oceanogr 55:1231-1247

Weisz JB, Lindquist N, Martens CS (2008) Do associated microbial abundances impact marine demosponge pumping rates and tissue densities? Oecologia 155:367-376

Wenzhöfer F, Glud RN (2004) Small-scale spatial and temporal variability in coastal benthic $\mathrm{O}_{2}$ dynamics: Effects of fauna activity. Limnol Oceanogr 49:1471-1481

Yang Z, Li Z (2012) Spatial distribution of prokaryotic symbionts and ammoxidation, denitrifier bacteria in marine sponge Astrosclera willeyana. Sci Rep 2:1-10

Zhang F, Jonas L, Lin H, Hill RT (2019) Microbially mediated nutrient cycles in marine sponges. FEMS Microbiol Ecol 95:fiz155

Publisher's Note Springer Nature remains neutral with regard to jurisdictional claims in published maps and institutional affiliations. 